\title{
Foreigners and Their Food: Constructing Otherness in Jewish, Christian, and Islamic Law
}

\author{
David M. Freidenreich \\ Berkeley: University of California Press, 2011. 325 pages.
}

Are dietary religious laws an obstacle to community relations between members of the Abrahamic faiths? The new edition of Pierre Birnbaum's Le Peuple et Les Gros, under the title Genèse du Populisme (Hachette Pluriel: 2012) explores how eating pork in Paris and other cities can be read as a sign of identity crisis in French society, as a way of excluding from the public space those who are different, in this case Jews and/or Muslims who follow dietary laws forbidding its consumption. Similarly, in Foreigners and Their Food: Constructing Otherness in Jewish, Christian, and Islamic Law, the question of community, religious laws about food, and a thorough analysis of the relevant sacred texts is revealing. This book explores how the Abrahamic faiths conceptualize "us" and "them" through the rules related to food preparation by those who are not "us" and the precise act of eating with "them." Moreover, it echoes an important marker of how communities remain segregated at meal time even though sharing food is seen as a familial, communal, and, most importantly, a sacred act.

Foreigners and Their Food opens with Freidenreich's personal struggle with food and its significance in deconstructing boundaries between different traditions. The author, an ordained rabbi, readily admits to a bias of comparative analysis when interpreting the texts and laws; however, this admission accentuates and delineates a thorough analysis and rich interpretation that the study of religion is yearning for in intertexual analysis.

The book begins with a discussion of "imagining otherness," one that alerts readers to the significance of food, its symbolic nature of inclusion/ exclusion, and the absence of any analysis as to how it impacts so many religious adherents who rely upon these laws but cannot critically reflect upon them as markers of "us" and "them." Freidenreich looks at what Leviticus, Deuteronomy, and similar traditional texts state, but he is clearly reaching for meanings that lie beyond the text. He points out as a general theme that " $\mathrm{Ab}$ sent from Biblical passages regarding these dietary laws, however, is any suggestion that the norms enjoined upon Israelites stand in opposition to non-Israelite practices" (p. 21).

Several diagrams appear in the book like moral algorithms. For example, one of them illustrates issues of purity and impurity, as well as holy and mun- 
dane, that mark categorical imperatives and separations of those religious laws that restrict the adherents' ability to share food with "others." For example, the argument demonstrates that impure items are outside the realm of the holy and thus become "foreign." Through this exemplary method, the author explores these categories to reach some more nebulous areas of dietary restrictions that do not identify the group to be either included/excluded from the specific community.

Part 2 focuses upon the Jewish sources of dietary restrictions and the concept of "otherness." The multiple slaughtering restrictions between Jew and Gentile can be overwhelming in this section, but at the end one is left with a different perspective through an illustrative diagram of "The Impact of Scholasticism on the Mishnah's Foreign Food Restrictions," which ultimately resounds in labeling Gentile items as non-permissible but not Gentiles themselves. Some of the discussions, which feature copious primary and secondary materials with an analysis of the Mishnah and Talmud, can be intimidating. Furthermore, the detailed references to texts and smaller sections, such as the laws of "Talmudic kitchens," can be perplexing for the average reader.

Part 3 introduces readers to the Christ-believing community and a fascinating overlap of Jews and Christians who share some sacred texts but are faced with the Gospels' revolutionary and illuminating freedom, especially Paul's statements about food. As Freidenreich states: "In his words to the Romans, Paul conveys a central message of his gospel to the gentiles, namely that gentile Christ-believers, because they are not Jews, are not bound by Jewish law" (p. 89). Food becomes the demarcation of "us" and "them," for Christians are no longer bound to the law of the foreigners, namely, the Jews.

The chapter entitled "How Could Their Food Not Be Impure?" provides the book's main insight, located within the author's voluminous analysis of texts and laws: "Most of the foreign food restrictions we have encountered thus far mark the otherness of foreigners without defining those foreigners in any detail. Daniel's refusal to eat the Babylonian King's food, for example, indicates that We are not Them but conveys no information either about the king or about the substance of the difference between Jews and gentiles" (p. 112).

Part 4 presents another way of imagining the "other" through Islamic sources on food relations. This sets the stage for a third imagining of "us" and "them," but one that is not limited to a single community. The author creates a maze of contrasting messages within the Makkan and Madinan sections of the Qur'an and includes the problems of inclusivity and exclusivity. Poignantly, Freidenreich states: "Qur'an 5.5 indicates that those who were given the Book are part of the holy community of believers in a certain respect, 
and are inferior to the Qur'an's believers in other respects: They are simultaneously like Us and unlike Us" (p. 141).

The final section leaves readers with a deep comparative analysis that analyzes why the ideas and values expressed through others and their food relate to issues of community and identity. This informative section guides readers to what is/is not permitted in the three traditions. It also discusses intra-faith debates about slaughtering, such as in the Sunni and Shia traditions. The author conveys a meaningful message to all communities: We imagine ourselves and foreigners as others through dietary laws and restrictions. Furthermore, he provides an invaluable resource not only for scholars seeking to delve deeply into more distinct contexts of food laws, but also how these laws create categorical imaginings of one another as "other."

Mehnaz M. Afridi Assistant Professor of Religious Studies Director, Holocaust, Genocide, and Interfaith Education Center Manhattan College, Bronx, NY 